\title{
Quantitative Analysis of $\mathrm{NK}_{1}$ Receptor in the Human Brain Using PET with ${ }^{18}$ F-FE-SPA-RQ
}

\author{
Masaki Okumura ${ }^{1,2}$, Ryosuke Arakawa ${ }^{1,2}$, Hiroshi Ito $^{1}$, Chie Seki ${ }^{1}$, Hidehiko Takahashi ${ }^{1}$, Harumasa Takano ${ }^{1}$, \\ Eisuke Haneda ${ }^{1,3}$, Ryuji Nakao ${ }^{4}$, Hidenori Suzuki ${ }^{3}$, Kazutoshi Suzuki ${ }^{4}$, Yoshiro Okubo ${ }^{2}$, and Tetsuya Suhara ${ }^{1}$ \\ ${ }^{I}$ Molecular Neuroimaging Group, Molecular Imaging Center, National Institute of Radiological Sciences, Chiba, Japan; ${ }^{2}$ Department of \\ Neuropsychiatry, Nippon Medical School, Tokyo, Japan; ${ }^{3}$ Department of Pharmacology, Nippon Medical School, Tokyo, Japan; and \\ ${ }^{4}$ Molecular Probe Group, Molecular Imaging Center, National Institute of Radiological Sciences, Chiba, Japan
}

\begin{abstract}
${ }^{18} \mathrm{~F}-$ fluoroethyl-SPA-RQ ( $\left.{ }^{18} \mathrm{~F}-\mathrm{FE}-\mathrm{SPA}-\mathrm{RQ}\right)$ was recently developed as a radioligand for the measurement of neurokinin $1\left(\mathrm{NK}_{1}\right)$ receptor with PET. In this study, we used ${ }^{18} \mathrm{~F}-\mathrm{FE}-\mathrm{SPA}-\mathrm{RQ}$ with PET to visualize and quantify $\mathrm{NK}_{1}$ receptor in the human brain. Methods: PET scans were performed on 7 healthy men after intravenous injection of ${ }^{18} \mathrm{~F}-\mathrm{FE}-\mathrm{SPA}-\mathrm{RQ}$. Binding potential $\left(\mathrm{BP}_{\mathrm{ND}}\right)$ was calculated by the indirect kinetic, simplified reference tissue model (SRTM), and ratio methods. The indirect kinetic method was used as the gold standard method and was compared with the SRTM method, with scan times of 180,270 , and $330 \mathrm{~min}$, and with the ratio method, with time integration intervals of $120-180,210-270$, and $300-330 \mathrm{~min}$. The cerebellum was used as the reference brain region. Results: Regional radioactivity was highest in the caudate head and putamen; mid level in the parahippocampus, cerebral cortex, and thalamus; and lowest in the cerebellum. $\mathrm{BP}_{\mathrm{ND}}$ values by the indirect kinetic method were $3.15 \pm 0.36,3.11 \pm 0.66,1.17 \pm 0.25$, and $0.46 \pm$ 0.14 in the caudate, putamen, parahippocampal region, and thalamus, respectively. For cerebral cortical regions, $\mathrm{BP}_{\mathrm{ND}}$ values by the indirect kinetic method were $0.94 \pm 0.23,0.82 \pm 0.15,0.76 \pm 0.15$, and $0.69 \pm 0.16$ in the occipital, temporal, frontal, and anterior cingulate cortices, respectively. $\mathrm{BP}_{\mathrm{ND}}$ values by the SRTM and ratio methods were in good agreement with those by the indirect kinetic method $(r=0.94-0.98)$. Conclusion: The regional distribution of ${ }^{18} \mathrm{~F}-\mathrm{FE}-\mathrm{SPA}-\mathrm{RQ}$ was in agreement with previous PET studies and postmortem studies of $\mathrm{NK}_{1}$ receptor in the human brain. The ratio method will be useful for clinical research of psychiatric disorders, for the estimation of $\mathrm{NK}_{1}$ receptor without arterial blood sampling and long dynamic PET.
\end{abstract}

Key Words: $\mathrm{NK}_{1}$ receptor; substance P; ${ }^{18} \mathrm{~F}-\mathrm{FE}-\mathrm{SPA}-\mathrm{RQ}$; PET; human brain

J Nucl Med 2008; 49:1749-1755

DOI: 10.2967/jnumed.108.054353

$\mathbf{T}$ achykinins are a family of neuropeptides that serve as neurotransmitters in the central nervous system (CNS) and peripheral nervous system (PNS). Three major mammalian

\footnotetext{
Received May 14, 2008; revision accepted Jul. 14, 2008.

For correspondence or reprints contact: Hiroshi Ito, Molecular Neuroimaging Group, Molecular Imaging Center, National Institute of Radiological Sciences 4-9-1, Anagawa, Inage-ku, Chiba, 263-8555, Japan.

E-mail: hito@nirs.go.jp

COPYRIGHT @ 2008 by the Society of Nuclear Medicine, Inc.
}

tachykinins-substance P (SP), neurokinin A, and neurokinin $\mathrm{B}$-are known, and they share a consensus amino acid sequence (-Phe-X-Gly-Leu-Met- $\mathrm{NH}_{2}$ ) in their carboxyl terminals (1-4). SP is a well-characterized neuropeptide, participating in neurotransmission by itself or synergistically with other neurotransmitters such as monoamines, acetylcholine, and glutamate in nerve terminals. Receptors for tachykinins-termed neurokinin $1\left(\mathrm{NK}_{1}\right)$, $\mathrm{NK}_{2}$, and $\mathrm{NK}_{3}$ receptors-have been identified (all are $\mathrm{G}$ protein-coupled 7-transmembrane receptors) and demonstrated to selectively show high affinity for SP, neurokinin $\mathrm{A}$, and neurokinin $\mathrm{B}$, respectively $(5,6) . \mathrm{NK}_{1}$ receptors are expressed in both CNS and PNS, whereas $\mathrm{NK}_{2}$ and $\mathrm{NK}_{3}$ receptors are expressed in PNS and CNS, respectively $(7,8)$. $\mathrm{SP}$ and $\mathrm{NK}_{1}$ receptors have been shown to play significant roles in pain (9), emesis $(10)$, neuroinflammation $(11,12)$, vasomotor control, and many gastrointestinal functions. Because the $\mathrm{SP}-\mathrm{NK}_{1}$ system is localized in brain regions (such as the striatum, amygdala, hypothalamus, raphe nucleus, and periaqueductal gray matter) that are involved in the regulation of affective behavior $(7,8)$, the activity of the central tachykinergic pathway mediated by $\mathrm{SP}$ and $\mathrm{NK}_{1}$ receptors is conceived to be mechanistically related to psychiatric conditions such as depression and anxiety disorder. Recent clinical trials of the $\mathrm{NK}_{1}$ receptor antagonist aprepitant have shown that the blockade of SP is a highly effective strategy for the prevention of chemotherapyinduced nausea and vomiting (13-15). Aprepitant was recently registered worldwide, and it represents an improvement for antiemetic control during chemotherapy. Early clinical studies also suggested that aprepitant may have antidepressant activity, implicating SP in the modulation of mood and anxiety in humans $(16,17)$. However, recent results from phase III clinical trials indicate that aprepitant is not effective for the treatment of depression (18).

A recently developed nonpeptide PET tracer that can permeate the blood-brain barrier, $\left[{ }^{18} \mathrm{~F}-2\right.$-fluoromethoxy-5(5-trifluoromethyl-tetrazol-1-yl)-benzyl]([2S,3S]2-phenylpiperidin-3-yl)-amine) $\left({ }^{18} \mathrm{~F}-\mathrm{SPA}-\mathrm{RQ}\right)(19)$, has been proven 
to bind to $\mathrm{NK}_{1}$ receptors with high affinity and selectivity and applied to in vivo imaging of human brains (20-22).

${ }^{18}$ F-fluoroethyl-SPA-RQ ( $\left.{ }^{18} \mathrm{~F}-\mathrm{FE}-\mathrm{SPA}-\mathrm{RQ}\right)$ was recently developed as a radioligand for the measurement of $\mathrm{NK}_{1}$ receptors (23). It is the fluoroethyl analog of ${ }^{18} \mathrm{~F}-\mathrm{SPA}-\mathrm{RQ}$ and was designed for brain imaging with reduced radioactive accumulation in bone by slowing the rate of defluorination. ${ }^{18} \mathrm{~F}-\mathrm{FE}-\mathrm{SPA}-\mathrm{RQ}$ has higher affinity for $\mathrm{NK}_{1}$ receptors than does ${ }^{18} \mathrm{~F}-\mathrm{SPA}-\mathrm{RQ}$ (human $\mathrm{NK}_{1}$ inhibitory concentration of $50 \%\left[\mathrm{IC}_{50}\right]=17$ and $67 \mathrm{pM}$ for ${ }^{18} \mathrm{~F}-\mathrm{FE}-$ SPA-RQ and ${ }^{18}$ F-SPA-RQ, respectively), and a small-animal PET study has been performed using ${ }^{18} \mathrm{~F}-\mathrm{FE}-\mathrm{SPA}-\mathrm{RQ}$ (24). In the present study, we aimed to quantify $\mathrm{NK}_{1}$ receptor binding in the human brain using ${ }^{18} \mathrm{~F}-\mathrm{FE}-\mathrm{SPA}-\mathrm{RQ}$ with arterial blood sampling and also to validate noninvasive methods for the quantification without arterial blood sampling.

\section{MATERIALS AND METHODS}

\section{Subjects}

A total of 7 healthy male subjects (age range, 20-31 y; mean \pm $\mathrm{SD}, 24.6 \pm 4.0 \mathrm{y}$ ) participated in this study. All subjects were free of any somatic, neurologic, or psychiatric disorders, and they had no history of current or previous drug abuse. After we described the study to the participants, written informed consent was obtained. The study was approved by the Ethics and Radiation Safety Committee of the National Institute of Radiologic Sciences, Chiba, Japan.

\section{Radioligand}

The $\mathrm{NK}_{1}$ receptor antagonist SPA-RQ (molecular weight, $450 \mathrm{M}$ ) was labeled with the positron emitter ${ }^{18} \mathrm{~F}$ (half-life, $109.8 \mathrm{~min})$. Details of the precursor compound, radiosynthesis, and quality control were described previously (23,25). Briefly, ${ }^{18} \mathrm{~F}-\mathrm{FCH}_{2} \mathrm{CH}_{2} \mathrm{Br}$ was prepared from ${ }^{18} \mathrm{~F}_{-} \mathrm{F}^{-}$and 2-bromoethyl triflate and purified by distillation. ${ }^{18} \mathrm{~F}$-Fluoroalkylation of the deprotonated phenolic hydroxyl group in the precursor with $\mathrm{FCH}_{2} \mathrm{CH}_{2} \mathrm{Br}$ in dimethyl formamide was performed at $120^{\circ} \mathrm{C}$ for $10 \mathrm{~min}$. The resultant ${ }^{18} \mathrm{~F}$-FE-SPA-RQ was purified by preparative high-performance liquid chromatography (HPLC). The final product was formulated in saline solution $(10 \mathrm{~mL})$ containing polysorbate $80(75 \mu \mathrm{L})$.

\section{PET Procedure}

A PET scanner system (ECAT EXACT HR+; CTI-Siemens) was used for all subjects, and a head restraint was used to minimize head movement. A transmission scan for attenuation correction was performed using a ${ }^{68} \mathrm{Ge}-{ }^{68} \mathrm{Ga}$ source, and a dynamic PET scan was performed after a 1-min intravenous slow-bolus injection of 210.2-228.8 MBq (221.6 $\pm 6.7 \mathrm{MBq})$ of ${ }^{18}$ F-FE-SPA-RQ. Specific radioactivity of ${ }^{18}$ F-FE-SPA-RQ was 281.8-487.7 GBq/ $\mu \mathrm{mol}(355.6 \pm 68.7 \mathrm{GBq} / \mu \mathrm{mol})$. Brain radioactivity was measured from 0 to $90 \mathrm{~min}(1 \mathrm{~min} \times 10,2 \mathrm{~min} \times 15,5$ $\min \times 10)$, from 120 to $180 \mathrm{~min}(5 \mathrm{~min} \times 12)$, from 210 to $270 \mathrm{~min}$ $(5 \mathrm{~min} \times 12)$, and from 300 to $330 \mathrm{~min}(5 \mathrm{~min} \times 6)$. MR images of the brain were acquired with a 1.5-T MRI scanner (Gyroscan NT; Philips). T1-weighted images were obtained at 1-mm slices.

\section{Arterial Blood Sampling and Metabolite Analysis}

To obtain the arterial input function, arterial blood samples were taken manually 49 times during PET. Each of the blood samples was centrifuged to obtain plasma and blood cell fractions, and the concentrations of radioactivity in whole blood and in plasma were measured.

The percentage of unchanged ${ }^{18} \mathrm{~F}-\mathrm{FE}-\mathrm{SPA}-\mathrm{RQ}$ in plasma was determined by HPLC in 29 of the total blood samples. Acetonitrile was added to each plasma sample, and samples were centrifuged. The supernatant was subjected to radio-HPLC analysis using an XBridge Prep C18 column (Waters) (mobile phase, 6:4 90\% acetonitrile:50 $\mathrm{mM}$ phosphoric acid). The plasma input function was defined as the radioactivity of plasma multiplied by the percentage of unchanged radioligand. Plasma protein binding was not determined in the present study.

\section{Regions of Interest}

All MR images were coregistered to the PET images using a statistical parametric mapping (SPM2) system. Regions of interest were drawn manually on summated PET images with reference to coregistered MRI and were defined for the caudate head; putamen; parahippocampal region; occipital, temporal, frontal, and anterior cingulate cortices; thalamus; and cerebellum, according to our previous study (26). The parahippocampal region included the hippocampus, posterior part of the parahippocampal gyrus, and uncus including the amygdala. Regional radioactivity was calculated for each frame, corrected for decay, and plotted versus time.

\section{Kinetics Model of ${ }^{18}$ F-FE-SPA-RQ}

The 3-compartment model (3CM) with 4 first-order rate constants was used to describe the kinetics of ${ }^{18} \mathrm{~F}-\mathrm{FE}-\mathrm{SPA}-\mathrm{RQ}$ in the brain. The 3 compartments were defined as follows: $C_{P}$, the radioactivity concentration of unchanged radioligand in plasma (arterial input function); $\mathrm{C}_{\mathrm{ND}}$, the radioactivity concentration of nondisplaceable radioligand in the brain, including nonspecifically bound and free radioligand; and $\mathrm{C}_{\mathrm{S}}$, the radioactivity concentration of radioligand specifically bound to receptors. The rate constants $\mathrm{K}_{1}$ and $\mathrm{k}_{2}$ represent the influx and efflux rates for radioligand diffusion through the blood-brain barrier, respectively. The rate constants $\mathrm{k}_{3}$ and $\mathrm{k}_{4}$ are the radioligand transfers between the compartments for nondisplaceable and specifically bound radioligand. This model can be described by the following equations:

$$
\begin{gathered}
\mathrm{dC}_{\mathrm{ND}}(\mathrm{t}) / \mathrm{dt}=\mathrm{K}_{1} \mathrm{C}_{\mathrm{P}}(\mathrm{t})-\left(\mathrm{k}_{2}+\mathrm{k}_{3}\right) \mathrm{C}_{\mathrm{ND}}(\mathrm{t})+\mathrm{k}_{4} \mathrm{C}_{\mathrm{S}}(\mathrm{t}), \\
\mathrm{dC}_{\mathrm{S}}(\mathrm{t}) / \mathrm{dt}=\mathrm{k}_{3} \mathrm{C}_{\mathrm{ND}}(\mathrm{t})-\mathrm{k}_{4} \mathrm{C}_{\mathrm{S}}(\mathrm{t}) \text {, and } \\
\mathrm{C}_{\mathrm{T}}(\mathrm{t})=\mathrm{C}_{\mathrm{ND}}(\mathrm{t})+\mathrm{C}_{\mathrm{S}}(\mathrm{t}) .
\end{gathered}
$$

$\mathrm{C}_{\mathrm{T}}(\mathrm{t})$ is the total radioactivity concentration in a brain region measured by PET.

\section{Calculation of ${ }^{18} \mathrm{~F}-\mathrm{FE}-\mathrm{SPA}-\mathrm{RQ}$ Binding Potential $\left(\mathrm{BP}_{\mathrm{ND}}\right)$}

${ }^{18} \mathrm{~F}-\mathrm{FE}-\mathrm{SPA}-\mathrm{RQ}$ binding was quantified by the indirect kinetic, simplified reference tissue model (SRTM), and ratio methods. In these methods, ${ }^{18} \mathrm{~F}$-FE-SPA-RQ bindings were expressed as $\mathrm{BP}_{\mathrm{ND}}$ relative to nondisplaceable bindings (27). We used the cerebellum as reference brain region because of its negligible $\mathrm{NK}_{1}$ receptor 


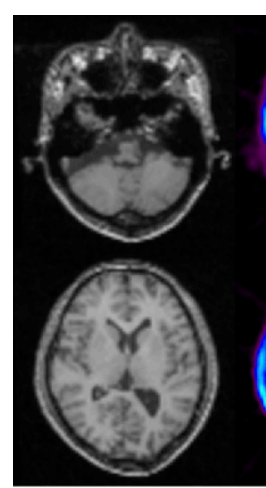

T1 image

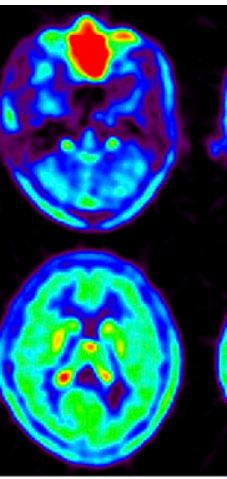

$0-90 \mathrm{~min}$

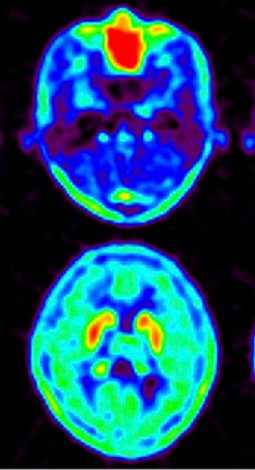

120-180 $\min$

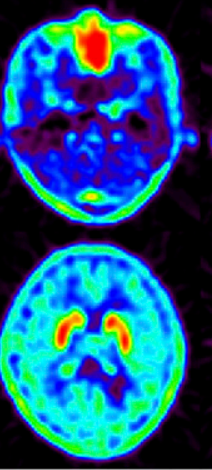

$210-270 \min$

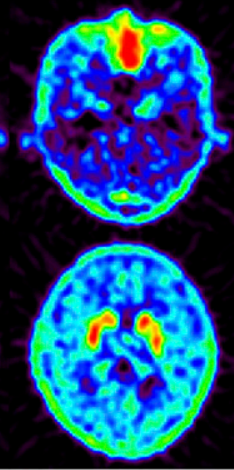

$300-330 \mathrm{~min}$
FIGURE 1. Typical summated PET images of ${ }^{18} \mathrm{~F}-\mathrm{FE}-\mathrm{SPA}-\mathrm{RQ}$ and $\mathrm{T} 1-$ weighted MR images. Upper row shows slice of cerebellum, and lower row shows slice of caudate, putamen, and cerebral cortex. density $(20,22,28)$. For these analyses, the software package PMOD (PMOD Technologies) was used.

Indirect Kinetic Method. With the cerebellum as reference region, $\mathrm{BP}_{\mathrm{ND}}$ can be expressed as:

$$
\mathrm{BP}_{\mathrm{ND}}=\mathrm{V}_{\mathrm{T}(\text { regions })} / \mathrm{V}_{\mathrm{T}(\text { cerebellum })}-1,
$$

where $\mathrm{V}_{\mathrm{T}(\text { regions) }}$ is the total distribution volume $\left(=\left[\mathrm{K}_{1} / \mathrm{k}_{2}\right]\left[\mathrm{k}_{3} / \mathrm{k}_{4}+\right.\right.$ 1]) of target regions and $V_{T(\text { cerebellum) }}$ is that of the cerebellum. $K_{1}$, $\mathrm{k}_{2}, \mathrm{k}_{3}$, and $\mathrm{k}_{4}$ values were determined by nonlinear least-squares curve fitting to the regional time-activity curves. In this analysis, blood volume $\left(\mathrm{V}_{\mathrm{b}}\right)$, which depends on the first-pass extraction fraction of the tracer, was assumed to be $0.04 \mathrm{~mL} / \mathrm{mL}$, with use of the radioactivity of whole blood to diminish the influence of the tracer remaining in the blood. In this study, the indirect kinetic method was used as the gold standard method (29).

SRTM Method. Assuming that both target and reference regions have the same level of nondisplaceable binding, the SRTM can be used to describe time-activity data in the target region as follows (30):

$$
\begin{aligned}
\mathrm{C}_{\mathrm{T}}(\mathrm{t})= & \mathrm{R}_{1} \mathrm{C}_{\mathrm{R}}(\mathrm{t})+\left(\mathrm{k}_{2}-\mathrm{R}_{1} \mathrm{k}_{2} /\left[1+\mathrm{BP}_{\mathrm{ND}}\right]\right) \mathrm{C}_{\mathrm{R}}(\mathrm{t}) * \\
& \exp \left(-\mathrm{k}_{2} \mathrm{t} /\left[1+\mathrm{BP}_{\mathrm{ND}}\right]\right),
\end{aligned}
$$

where $\mathrm{R}_{1}$ is the ratio of $\mathrm{K}_{1} / \mathrm{K}_{1}{ }^{\prime}\left(\mathrm{K}_{1}\right.$, influx rate constant for the brain region; $\mathrm{K}_{1}{ }^{\prime}$, influx rate constant for the reference region), $\mathrm{C}_{\mathrm{R}}(\mathrm{t})$ is the radioactivity concentration in the reference region (cerebellum), and $*$ denotes the convolution integral. Using this method, 3 parameters $\left(\mathrm{R}_{1}, \mathrm{k}_{2}\right.$, and $\left.\mathrm{BP}_{\mathrm{ND}}\right)$ were estimated by a nonlinear curve-fitting procedure. Scan data up to 180,270 , and $330 \mathrm{~min}$ were used.

Ratio Method. In the ratio method, $\mathrm{BP}_{\mathrm{ND}}$ can be expressed as:

$$
\mathrm{BP}_{\mathrm{ND}}=\mathrm{AUC}_{(\text {regions })} / \mathrm{AUC}_{(\text {cerebellum })}-1,
$$

where $\mathrm{AUC}_{\text {(regions) }}$ is the area under the time-activity curve of target regions and $\mathrm{AUC}_{\text {(cerebellum) }}$ is the time-activity curve of the cerebellum. The integration intervals of 120-180, 210-270, and 300-330 min were used.

\section{RESULTS}

Typical summated PET images of 4 time periods and T1-weighted MR images are shown in Figure 1. Typical time-activity curves in the brain showed that regional radioactivity was highest in the putamen and caudate (Fig. 2). The next highest region was the parahippocampus, followed by the cerebral cortices and thalamus. Among cerebral

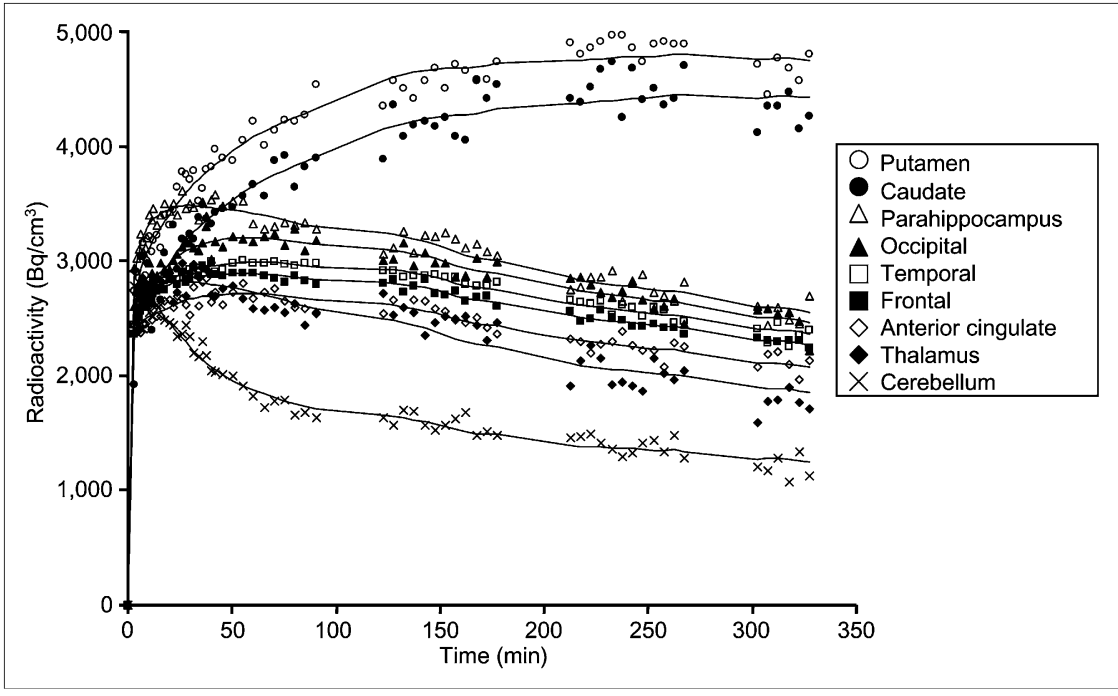

FIGURE 2. Typical time-activity curves of ${ }^{18} \mathrm{~F}-\mathrm{FE}-\mathrm{SPA}-\mathrm{RQ}$ in brain. Time-activity curves of all regions could be described by $3 \mathrm{CM}$. 


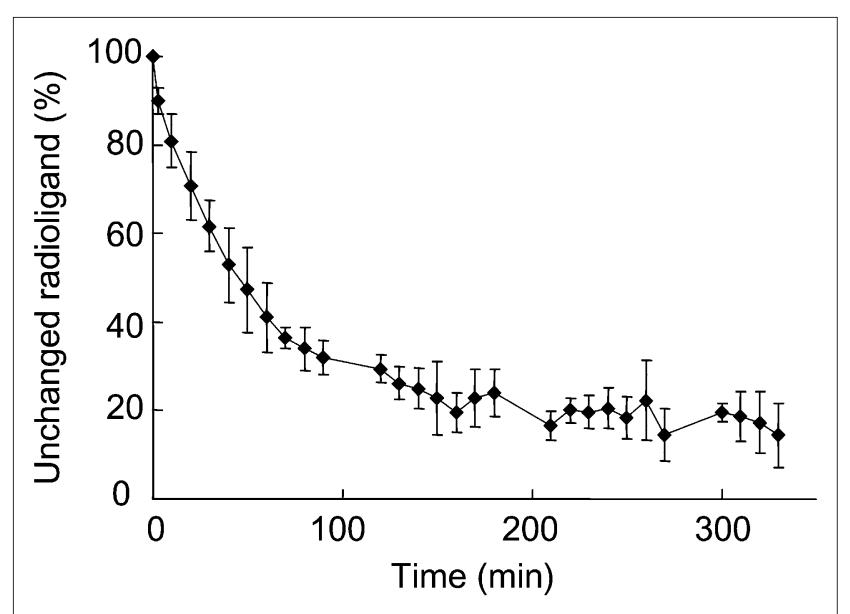

FIGURE 3. Average percentage of unchanged ${ }^{18} \mathrm{~F}-\mathrm{FE}-\mathrm{SPA}-\mathrm{RQ}$ in plasma. Bars indicate $1 \mathrm{SD}$.

cortices, the occipital cortex showed the highest radioactivity. Lowest radioactivity was shown in the cerebellum.

In this study, the fraction of unchanged ${ }^{18} \mathrm{~F}-\mathrm{FE}-\mathrm{SPA}-\mathrm{RQ}$ in plasma could not be measured by HPLC analysis in 3 of the 7 subjects because of low radioactivity in blood samples. So, the average of the fractions of unchanged ${ }^{18} \mathrm{~F}-\mathrm{FE}-$ SPA-RQ in plasma of the other 4 subjects was used for these 3 subjects for the indirect kinetic method. The average percentage fraction of unchanged ${ }^{18} \mathrm{~F}-\mathrm{FE}-\mathrm{SPA}-$ RQ in plasma of the 4 subjects was $90.0 \% \pm 2.9 \%$ at $3 \mathrm{~min}, 80.9 \% \pm 6.1 \%$ at $10 \mathrm{~min}, 32.0 \% \pm 3.9 \%$ at $90 \mathrm{~min}$, $23.9 \% \pm 5.3 \%$ at $180 \mathrm{~min}, 14.6 \% \pm 5.9 \%$ at $270 \mathrm{~min}$, and $14.4 \% \pm 7.3 \%$ at $330 \mathrm{~min}$ (Fig. 3).

The rate constants for the 9 regions determined by the kinetic approach using the $3 \mathrm{CM}$ with arterial input function are shown in Table 1. For the cerebellum, the 2-compartment model (2CM) without specific binding compartment was also used. Akaike information criteria of the $3 \mathrm{CM}$ were signifi- cantly lower than those of the $2 \mathrm{CM}$ in the cerebellum (290 \pm 28 vs. $409 \pm 25, P<0.0001$; paired $t$ statistics).

The $\mathrm{BP}_{\mathrm{ND}}$ values of all brain regions calculated by all methods are shown in Table 2. $\mathrm{BP}_{\mathrm{ND}}$ values by the SRTM method with a scan time of 330 min showed the best correlation with those by the indirect kinetic method ( $r=$ 0.98) (Fig. 4A). The SRTM method with scan times of 270 and $180 \mathrm{~min}$ and the ratio method with time integration intervals of 300-330, 210-270, and 120-180 min were also in good agreement with the indirect kinetic method in $\mathrm{BP}_{\mathrm{ND}}$ values $(r=0.94-0.97)$ (Figs. 4B and 4C; Fig. 5). The $\mathrm{BP}_{\mathrm{ND}}$ values, except for the caudate and putamen by the SRTM method with a scan time of $180 \mathrm{~min}$ and the ratio method with a time integration interval of $120-180 \mathrm{~min}$, were also in good agreement with the indirect kinetic method (SRTM, $r=0.94, y=0.70 x+0.20$; ratio method, $r=0.94, y=0.69 x+0.20)$.

The $\mathrm{BP}_{\mathrm{ND}}$ values determined by the kinetic approach $\left(=\mathrm{k}_{3} / \mathrm{k}_{4}\right)$ were $4.39 \pm 3.93$ and $5.94 \pm 3.44$ in the caudate and putamen. Those in the other regions were much smaller and varied widely.

\section{DISCUSSION}

After the intravenous injection of ${ }^{18} \mathrm{~F}-\mathrm{FE}-\mathrm{SPA}-\mathrm{RQ}$, radioactivity was highest in the caudate and putamen and lowest in the cerebellum. $\mathrm{BP}_{\mathrm{ND}}$ values in the caudate and putamen by the indirect kinetic method were $3.15 \pm 0.36$ and $3.11 \pm$ 0.66 , respectively, almost the same as in the previous human PET study with ${ }^{18} \mathrm{~F}-\mathrm{SPA}-\mathrm{RQ}(3.08 \pm 0.48$ in the caudate and $3.71 \pm 1.00$ in the putamen) (22). The parahippocampal region and cerebral cortices showed moderate uptake, and the occipital cortex showed the highest uptake among the cerebral cortices. The thalamus showed relatively low uptake. The uptake shown in these regions was almost the same order of progression as the uptake in previous human PET studies with ${ }^{18} \mathrm{~F}-\mathrm{SPA}-\mathrm{RQ}$ and autoradiographic studies of the human postmortem brain

TABLE 1

Rate Constants for Each Brain Region Determined by Kinetic Approach Using 3CM with Arterial Input Function

\begin{tabular}{|c|c|c|c|c|c|}
\hline \multirow[b]{2}{*}{ Region } & \multicolumn{4}{|c|}{ Rate constant } & \multirow[b]{2}{*}{ Total distribution volume } \\
\hline & $\overline{\mathrm{K}_{1}(\mathrm{~mL} / \mathrm{mL} / \mathrm{min})}$ & $\mathrm{k}_{2}\left(\min ^{-1}\right)$ & $\mathrm{k}_{3}\left(\min ^{-1}\right)$ & $\mathrm{k}_{4}\left(\min ^{-1}\right)$ & \\
\hline Putamen & $0.111 \pm 0.019$ & $0.036 \pm 0.016$ & $0.081 \pm 0.040$ & $0.014 \pm 0.003$ & $21.3 \pm 3.4$ \\
\hline Caudate & $0.088 \pm 0.018$ & $0.023 \pm 0.018$ & $0.061 \pm 0.067$ & $0.011 \pm 0.005$ & $21.5 \pm 1.7$ \\
\hline Parahippocampus & $0.140 \pm 0.023$ & $0.033 \pm 0.007$ & $0.027 \pm 0.020$ & $0.015 \pm 0.006$ & $11.3 \pm 1.4$ \\
\hline Occipital lobe & $0.127 \pm 0.017$ & $0.065 \pm 0.038$ & $0.089 \pm 0.057$ & $0.021 \pm 0.007$ & $10.0 \pm 1.1$ \\
\hline Temporal lobe & $0.106 \pm 0.050$ & $0.050 \pm 0.025$ & $0.067 \pm 0.038$ & $0.020 \pm 0.003$ & $9.5 \pm 0.9$ \\
\hline Frontal lobe & $0.108 \pm 0.011$ & $0.041 \pm 0.011$ & $0.052 \pm 0.023$ & $0.021 \pm 0.002$ & $9.1 \pm 0.9$ \\
\hline Anterior cingulate cortex & $0.115 \pm 0.014$ & $0.064 \pm 0.018$ & $0.072 \pm 0.027$ & $0.019 \pm 0.005$ & $8.8 \pm 0.9$ \\
\hline Thalamus & $0.112 \pm 0.019$ & $0.043 \pm 0.018$ & $0.038 \pm 0.026$ & $0.019 \pm 0.003$ & $7.6 \pm 0.9$ \\
\hline \multicolumn{6}{|l|}{ Cerebellum } \\
\hline $3 \mathrm{CM}$ & $0.115 \pm 0.017$ & $0.051 \pm 0.015$ & $0.017 \pm 0.008$ & $0.013 \pm 0.003$ & $5.2 \pm 0.4$ \\
\hline $2 \mathrm{CM}$ & $0.089 \pm 0.014$ & $0.019 \pm 0.002$ & & & $4.6 \pm 0.3$ \\
\hline
\end{tabular}

Values are mean \pm SD. For cerebellum, both $2 \mathrm{CM}$ and $3 \mathrm{CM}$ were applied. 
TABLE 2

$\mathrm{BP}_{\mathrm{ND}}$ Values for Each Brain Region with All Methods

\begin{tabular}{|c|c|c|c|c|c|c|c|}
\hline \multirow[b]{3}{*}{ Region } & \multicolumn{7}{|c|}{ Method } \\
\hline & \multirow[b]{2}{*}{ Indirect kinetic } & \multicolumn{3}{|c|}{ SRTM (min) } & \multicolumn{3}{|c|}{ Ratio (min) } \\
\hline & & 330 & 270 & 180 & $300-330$ & $210-270$ & $120-180$ \\
\hline Putamen & $3.11 \pm 0.66$ & $2.43 \pm 0.33$ & $2.33 \pm 0.32$ & $2.20 \pm 0.27$ & $2.62 \pm 0.40$ & $2.25 \pm 0.28$ & $1.81 \pm 0.19$ \\
\hline Caudate & $3.15 \pm 0.36$ & $2.14 \pm 0.24$ & $2.02 \pm 0.22$ & $1.91 \pm 0.20$ & $2.31 \pm 0.40$ & $1.98 \pm 0.26$ & $1.57 \pm 0.17$ \\
\hline Parahippocampus & $1.17 \pm 0.25$ & $1.04 \pm 0.16$ & $1.02 \pm 0.12$ & $1.01 \pm 0.12$ & $1.11 \pm 0.22$ & $1.05 \pm 0.16$ & $1.03 \pm 0.20$ \\
\hline Occipital lobe & $0.94 \pm 0.23$ & $0.88 \pm 0.14$ & $0.92 \pm 0.07$ & $0.90 \pm 0.13$ & $0.97 \pm 0.16$ & $0.94 \pm 0.16$ & $0.95 \pm 0.17$ \\
\hline Temporal lobe & $0.82 \pm 0.15$ & $0.77 \pm 0.11$ & $0.79 \pm 0.08$ & $0.78 \pm 0.11$ & $0.85 \pm 0.15$ & $0.83 \pm 0.15$ & $0.79 \pm 0.15$ \\
\hline Frontal lobe & $0.76 \pm 0.15$ & $0.72 \pm 0.12$ & $0.74 \pm 0.07$ & $0.73 \pm 0.11$ & $0.79 \pm 0.17$ & $0.76 \pm 0.15$ & $0.75 \pm 0.15$ \\
\hline Anterior cingulate cortex & $0.69 \pm 0.16$ & $0.66 \pm 0.15$ & $0.67 \pm 0.13$ & $0.71 \pm 0.17$ & $0.70 \pm 0.16$ & $0.69 \pm 0.13$ & $0.67 \pm 0.13$ \\
\hline Thalamus & $0.46 \pm 0.14$ & $0.46 \pm 0.13$ & $0.51 \pm 0.10$ & $0.49 \pm 0.14$ & $0.45 \pm 0.12$ & $0.45 \pm 0.13$ & $0.49 \pm 0.16$ \\
\hline
\end{tabular}

Values are mean $\pm \mathrm{SD}$.

$(20,22,28)$. In a previous autoradiographic study using ${ }^{3} \mathrm{H}-$ GR205171, the maximum number of binding sites for $\mathrm{NK}_{1}$ receptor in the striatum was 6 times as much as in the cortex (31), a result in accordance with the $\mathrm{BP}_{\mathrm{ND}}$ values in these regions in the present study.

In this study, the indirect kinetic method with arterial blood sampling was used as the gold standard method, because $\mathrm{BP}_{\mathrm{ND}}$ determined by the kinetic approach as $\mathrm{k}_{3} / \mathrm{k}_{4}$ showed wide variation. The $\mathrm{BP}_{\mathrm{ND}}$ values in all brain regions determined by the SRTM method (with scan times of 330,270 , and $180 \mathrm{~min}$ ) and by the ratio method (with time integration intervals of 300-330, 210-270, and 120$180 \mathrm{~min}$ ) were in good agreement with those determined by the indirect kinetic method. Although good correlations were observed in $\mathrm{BP}_{\mathrm{ND}}$ values among the methods, $\mathrm{BP}_{\mathrm{ND}}$ was underestimated in the caudate and putamen using the
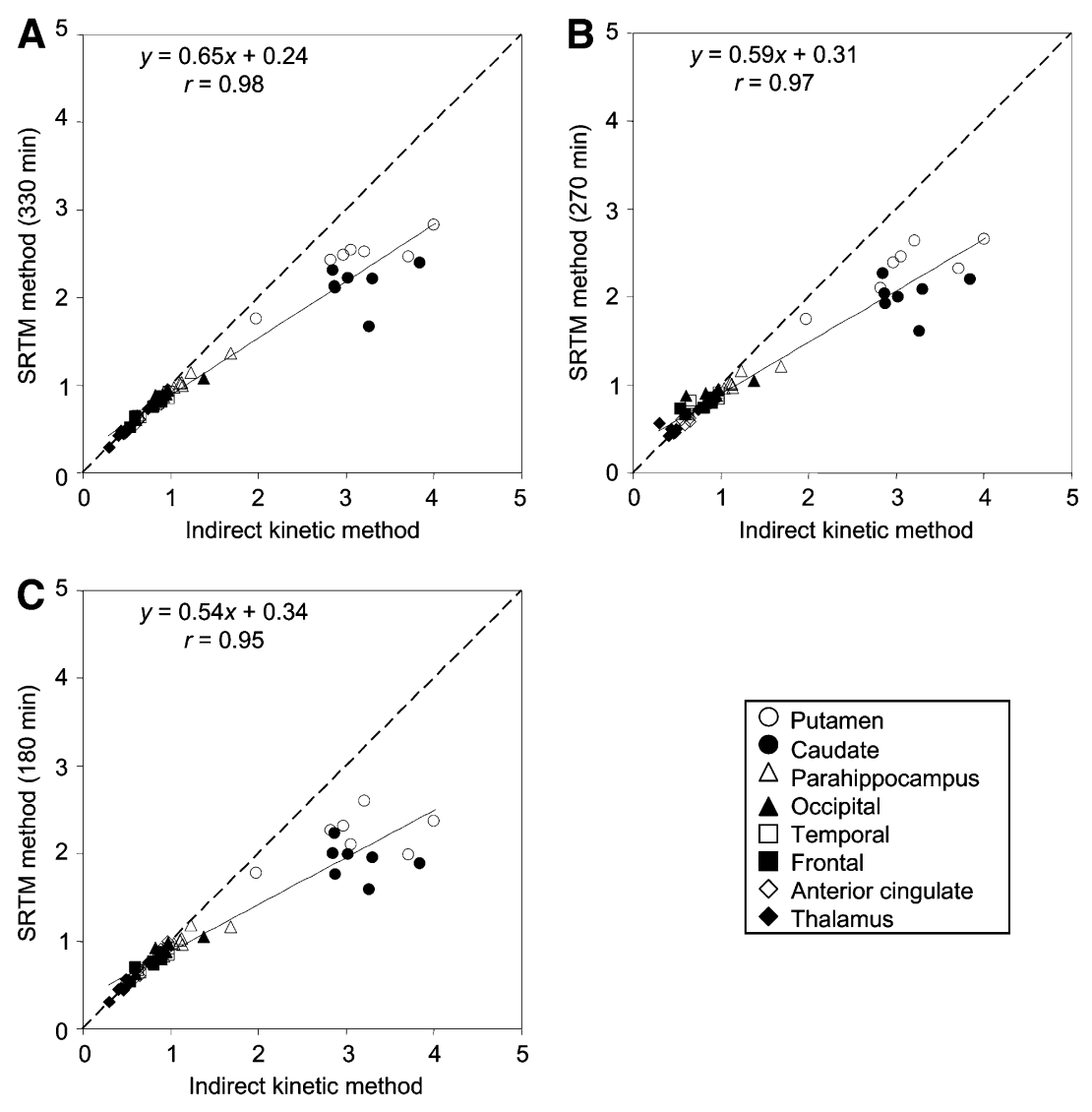

FIGURE 4. Correlation among $\mathrm{BP}_{\mathrm{ND}}$ values in all brain regions estimated by indirect kinetic and SRTM methods, with scan times of $330(\mathrm{~A}), 270(\mathrm{~B})$, and 180 (C) $\min$. 
FIGURE 5. Correlation among $\mathrm{BP}_{\mathrm{ND}}$ values in all brain regions estimated by indirect kinetic and ratio methods, with time integration intervals of $300-330(A)$, 210-270 (B), and 120-180 (C) min.
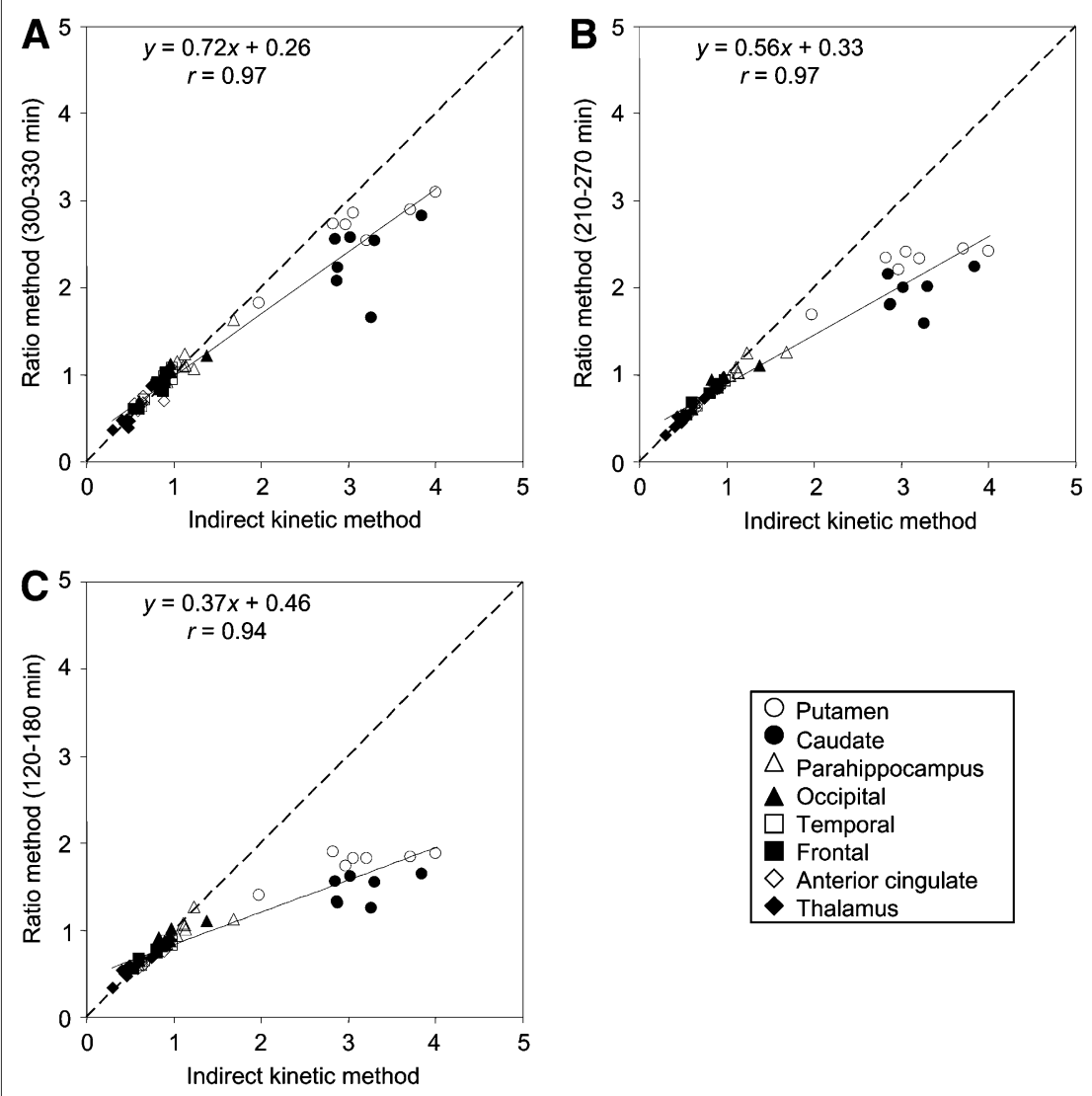

SRTM and ratio methods. The underestimations of $\mathrm{BP}_{\mathrm{ND}}$ were $32 \%$ and $34 \%$ in the caudate and $22 \%$ and $16 \%$ in the putamen for the SRTM method (with a scan time of 330 min) and the ratio method (with a time integration interval of 300-330 $\mathrm{min}$ ), respectively. More underestimation was observed in the caudate and putamen with the shorter scan time in the SRTM method and with the earlier time integration interval in the ratio method. The reason might be that striatal radioactivity in some subjects did not reach a peak by $330 \mathrm{~min}$. However, the $\mathrm{BP}_{\mathrm{ND}}$ values of the other regions calculated by the SRTM method (with a scan time of $180 \mathrm{~min}$ ) and the ratio method (with a time integration interval of 120-180 min) were not greatly underestimated, indicating that the scan time can be shortened to $180 \mathrm{~min}$. Although the indirect kinetic method was considered as the gold standard method, it required a long PET time and arterial blood sampling, an invasive procedure sometimes difficult for patients with psychiatric disorders. The ratio method, which does not require a long PET scanning time and arterial blood sampling, would surely be preferable for clinical investigations. The ratio method, with a time integration interval of 300-330 min, seemed most suitable because the correlation coefficient with the indirect kinetic method was highest and the slope of the regression line was nearest to 1 .

The time-activity curves in the cerebellum were well described by the $3 \mathrm{CM}$ rather than the $2 \mathrm{CM}$. Similar results were reported for several PET radioligands, with the kinetics in the reference region also being evaluated using the 3CM $(29,32,33)$. The results could be explained if the cerebellum would contain specific bindings for $\mathrm{NK}_{1}$ receptors. However, previous autoradiographic studies showed that the density of $\mathrm{NK}_{1}$ receptors in the cerebellum was low (22), and a previous PET study with ${ }^{18} \mathrm{~F}-\mathrm{SPA}-\mathrm{RQ}$ showed that there was no change in the cerebellar signal before and after high blocking doses of the $\mathrm{NK}_{1}$ receptor antagonist aprepitant (20). Another possible explanation for the results was that the compartments of free and nonspecific binding might have been separated by the kinetic analysis. In addition, ${ }^{18}$ F-FE-SPA-RQ showed defluorination during the later scans, and bone uptake of ${ }^{18} \mathrm{~F}$ might influence the radioactivity in the cerebral cortex and cerebellum adjacent to the skull (although ${ }^{18} \mathrm{~F}-\mathrm{FE}-\mathrm{SPA}-\mathrm{RQ}$ showed reduced radioactive accumulation in bone, compared with ${ }^{18}$ F-SPA-RQ (23)).

\section{CONCLUSION}

${ }^{18} \mathrm{~F}-\mathrm{FE}-\mathrm{SPA}-\mathrm{RQ}$ is a suitable radioligand for PET measurement of $\mathrm{NK}_{1}$ receptors in the human brain. The $3 \mathrm{CM}$ could well describe the brain kinetics of ${ }^{18} \mathrm{~F}-\mathrm{FE}-\mathrm{SPA}-\mathrm{RQ}$. Because the ratio method does not require long scanning times and arterial blood sampling, this method would be useful for clinical research on psychiatric disorders. 


\section{ACKNOWLEDGMENTS}

We thank Dr. Fumitoshi Kodaka, Dr. Tatsui Otsuka, Katsuyuki Tanimoto, Takahiro Shiraishi, and Akira Ando for their assistance in performing the PET experiments at the National Institute of Radiological Sciences. We also thank Yoshiko Fukushima of the National Institute of Radiological Sciences for her help as clinical research coordinator. This study was supported by a consignment expense for the Molecular Imaging Program on Research Base for PET Diagnosis from the Ministry of Education, Culture, Sports, Science and Technology (MEXT), Japanese Government.

\section{REFERENCES}

1. Baker KG, Halliday GM, Hornung JP, Geffen LB, Cotton RG, Tork I. Distribution, morphology and number of monoamine-synthesizing and substance P-containing neurons in the human dorsal raphe nucleus. Neuroscience. 1991; 42:757-775.

2. Nicholas AP, Pieribone VA, Arvidsson U, Hokfelt T. Serotonin-, substance $\mathrm{P}$ - and glutamate/aspartate-like immunoreactivities in medullo-spinal pathways of rat and primate. Neuroscience. 1992;48:545-559.

3. Sergeyev V, Hokfelt T, Hurd Y. Serotonin and substance P co-exist in dorsal raphe neurons of the human brain. Neuroreport. 1999;10:3967-3970.

4. Vincent SR, Satoh K, Armstrong DM, Panula P, Vale W, Fibiger HC. Neuropeptides and NADPH-diaphorase activity in the ascending cholinergic reticular system of the rat. Neuroscience. 1986;17:167-182.

5. Masu Y, Nakayama K, Tamaki H, Harada Y, Kuno M, Nakanishi S. cDNA cloning of bovine substance-K receptor through oocyte expression system. Nature. 1987;329:836-838.

6. Nakanishi S. Mammalian tachykinin receptors. Annu Rev Neurosci. 1991; 14:123-136.

7. Ding YQ, Shigemoto R, Takada M, Ohishi H, Nakanishi S, Mizuno N. Localization of the neuromedin $\mathrm{K}$ receptor $\left(\mathrm{NK}_{3}\right)$ in the central nervous system of the rat. J Comp Neurol. 1996;364:290-310.

8. Nakaya Y, Kaneko T, Shigemoto R, Nakanishi S, Mizuno N. Immunohistochemical localization of substance $\mathrm{P}$ receptor in the central nervous system of the adult rat. J Comp Neurol. 1994;347:249-274.

9. Snider WD, McMahon SB. Tackling pain at the source: new ideas about nociceptors. Neuron. 1998;20:629-632.

10. Sanger GJ. Neurokinin $\mathrm{NK}_{1}$ and $\mathrm{NK}_{3}$ receptors as targets for drugs to treat gastrointestinal motility disorders and pain. Br J Pharmacol. 2004;141:13031312.

11. Kincy-Cain T, Bost KL. Increased susceptibility of mice to Salmonella infection following in vivo treatment with the substance $\mathrm{P}$ antagonist, spantide II. J Immunol. 1996;157:255-264.

12. Metwali A, Blum AM, Elliott DE, Setiawan T, Weinstock JV. Cutting edge: hemokinin has substance P-like function and expression in inflammation. J Immunol. 2004;172:6528-6532.

13. Hesketh PJ, Van Belle S, Aapro M, et al. Differential involvement of neurotransmitters through the time course of cisplatin-induced emesis as revealed by therapy with specific receptor antagonists. Eur J Cancer. 2003; 39:1074-1080

14. Hesketh PJ, Grunberg SM, Gralla RJ, et al. The oral neurokinin-1 antagonist aprepitant for the prevention of chemotherapy-induced nausea and vomiting: a multinational, randomized, double-blind, placebo-controlled trial in patients receiving high-dose cisplatin-the Aprepitant Protocol 052 Study Group. J Clin Oncol. 2003;21:4112-4119.

15. de Wit R, Herrstedt J, Rapoport B, et al. Addition of the oral NK1 antagonist aprepitant to standard antiemetics provides protection against nausea and vomiting during multiple cycles of cisplatin-based chemotherapy. J Clin Oncol. 2003;21:4105-4111.

16. Kramer MS, Cutler N, Feighner J, et al. Distinct mechanism for antidepressant activity by blockade of central substance P receptors. Science. 1998;281:16401645 .

17. Kramer MS, Winokur A, Kelsey J, et al. Demonstration of the efficacy and safety of a novel substance $\mathrm{P}\left(\mathrm{NK}_{1}\right)$ receptor antagonist in major depression. Neuropsychopharmacology. 2004;29:385-392.

18. Keller M, Montgomery S, Ball W, et al. Lack of efficacy of the substance p (neurokinin1 receptor) antagonist aprepitant in the treatment of major depressive disorder. Biol Psychiatry. 2006;59:216-223.

19. Solin O, Eskola O, Hamill TG, et al. Synthesis and characterization of a potent, selective, radiolabeled substance-P antagonist for $\mathrm{NK}_{1}$ receptor quantitation: ([ ${ }^{18}$ F]SPA-RQ). Mol Imaging Biol. 2004;6:373-384.

20. Bergstrom M, Hargreaves RJ, Burns HD, et al. Human positron emission tomography studies of brain neurokinin 1 receptor occupancy by aprepitant. Biol Psychiatry. 2004;55:1007-1012.

21. Hargreaves $\mathrm{R}$. Imaging substance $\mathrm{P}$ receptors $\left(\mathrm{NK}_{1}\right)$ in the living human brain using positron emission tomography. J Clin Psychiatry. 2002;63(suppl 11):S18S24.

22. Hietala J, Nyman MJ, Eskola O, et al. Visualization and quantification of neurokinin-1 $\left(\mathrm{NK}_{1}\right)$ receptors in the human brain. Mol Imaging Biol. 2005; 7:262-272.

23. Hamill T, Ryan C, Krause S, et al. The synthesis and in vivo characterization of $\left[{ }^{18} \mathrm{~F}\right] \mathrm{FESPARQ}$, a neurokinin-1 $\left(\mathrm{NK}_{1}\right)$ receptor PET ligand [abstract]. J Labelled Comp Radiopharm. 2003;46(suppl 1):S35.

24. Haneda E, Higuchi M, Maeda J, et al. In vivo mapping of substance P receptors in brains of laboratory animals by high-resolution imaging systems. Synapse. 2007;61:205-215.

25. Zhang MR, Maeda J, Furutsuka K, et al. $\left[{ }^{18} \mathrm{~F}\right]$ FMDAA1106 and $\left[{ }^{18} \mathrm{~F}\right] \mathrm{FE}-$ DAA1106: two positron-emitter labeled ligands for peripheral benzodiazepine receptor (PBR). Bioorg Med Chem Lett. 2003;13:201-204.

26. Ito H, Takahashi H, Arakawa R, Takano H, Suhara T. Normal database of dopaminergic neurotransmission system in human brain measured by positron emission tomography. Neuroimage. 2008;39:555-565.

27. Innis RB, Cunningham VJ, Delforge J, et al. Consensus nomenclature for in vivo imaging of reversibly binding radioligands. J Cereb Blood Flow Metab. 2007;27:1533-1539.

28. Caberlotto L, Hurd YL, Murdock P, et al. Neurokinin 1 receptor and relative abundance of the short and long isoforms in the human brain. Eur J Neurosci. 2003; 17:1736-1746.

29. Ito H, Sudo Y, Suhara T, Okubo Y, Halldin C, Farde L. Error analysis for quantification of $\left[{ }^{11} \mathrm{C}\right] \mathrm{FLB} 457$ binding to extrastriatal $\mathrm{D}_{2}$ dopamine receptors in the human brain. Neuroimage. 2001;13:531-539.

30. Lammertsma AA, Hume SP. Simplified reference tissue model for PET receptor studies. Neuroimage. 1996;4:153-158.

31. Griffante C, Carletti R, Andreetta F, Corsi M. $\left[{ }^{3} \mathrm{H}\right] \mathrm{GR} 205171$ displays similar $\mathrm{NK}_{1}$ receptor binding profile in gerbil and human brain. Br J Pharmacol. 2006; 148:39-45.

32. Farde L, Ito H, Swahn CG, Pike VW, Halldin C. Quantitative analyses of carbonyl-carbon-11-WAY-100635 binding to central 5-hydroxytryptamine-1A receptors in man. J Nucl Med. 1998;39:1965-1971.

33. Lundberg J, Odano I, Olsson H, Halldin C, Farde L. Quantification of ${ }^{11} \mathrm{C}$-MADAM binding to the serotonin transporter in the human brain. $\mathrm{J} \mathrm{Nucl}$ Med. 2005;46:1505-1515. 